\title{
De Bathe's And Lynall Thomas' Armour-Plates
}

\section{Lynall Thomas Esq.}

To cite this article: Lynall Thomas Esq. (1861) De Bathe's And Lynall Thomas' Armour-Plates, Royal United Services Institution. Journal, 5:18, 342-348, DOI: 10.1080/03071846109416755

To link to this article: http://dx.doi.org/10.1080/03071846109416755

\section{曲 Published online: 25 Sep 2009.}

Submit your article to this journal 정

Џ Article views: 2

Q View related articles $\sqsubset$ 


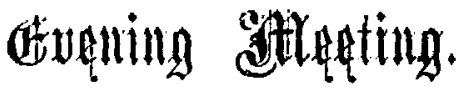

Friday, May 31, 1861.

Captais M. S. NOLLOTH, R.N., in the Chair.

\section{DE BATHE'S AND LYNALL THOMAS' ARMOUR-PLATES.}

\section{Br Lrasull Thomag, Esq.}

Hariva attended the discussion at the Institution of Naral Architects without having had an opportunity of taking part in it, I araịl myself of this opportunity of exhibiting and cxplaining a method of affording resistance to the penetration of shot and shell into the sides of a ship, which may perhaps be worthy of your consideration, as I beliere, from long and carnest consideration, added to considerable experience, of the effect produced by shot generally, that the solid iron plate on a coating of timber, as adopted in the general service, is one of the worst which could be conceived. My chicf reason for this opinion is, that the whole force of the blow coming at once upon the plate, its effect is felt instantaneously through the whole thickness of the plate in the direction in which the shot is moring. An immense thickness of metal is therefore required, and consequently an chormous weight upon the sides of, and strain upon the ressel generally; the joint efforts of which make the remedy almost as bad as the disease. With respect to the strength afforded by the woolen back, I have to observe, that in all my experiments I have found the wooden foundation to favour rather than prevent the penetration of the shot through the iron plate. There are sereral methods for prerenting the penetration of shot or shell into the sides of a ship. 1st. By constructing these silles entirely of iron, thus opposing plates of solid metal to the impact of the projectile. 2nd. By sloping the sides in such a manner as to deflect the projectile: 3rd. By corering the sides with some sibstance which shall receive the first impact of the projectile, dispersing the force before complete penetration can take place.

The objection to the first of these methods is, that with the continual improvements in the means of attack, so great a thickness of metal would be required, that no ship conld carry it withont great detriment to her seagoing qualities.

With regard to the second method, namely, the sloping sides, the same objection holds good; for, although a less thickness of metal might be found sufficient to dirert the blow of a shot when fired at ships thus constructed, unless under certain circumstances, yet such ressels must, of necessity, lie so low in the rater, that in engaging land batteries or vessels much higher out of the water than themselves, the sides would be liable to penetration, unless the metal plates were of a thickness identical with those required for a ressel of an ordinary form, so that a still greater weight of metal wonld 
be necessary, innsmuch as more would lie requirel to corer at sloping than *II upright side, the surface being greater.

Up to the present time, I believe that the efficiency of the sloping side has only been tested with "round" shot, which are more easily deflected by the slope than flat-lieaded shot of an elongated form, for the following reasoll. The ordinary sperical shat only preserres sufficient force to penetrate an "ordinary" iron plate (i.e. 4 inches) for a short portion of its flight. Consequently, unless at point-blank distances, it is useless to attempt to penetrate an iron plate with roumd shot. With a heary clongated shot, however, this penetration conld be accomplished from a greater distance.

Now, supposing the gom to loe fired with some eleration, the sloping sides rould be rather favourable to penetration than otherrise, in proportion as the angle of the shot's descent approached that of the sloping side.

It has hitherto been a received opinion that the axis of an clongated shot remains always parallel to itself during the shot's flight, in which ease its penetrative powers would be considerably decreased as the distance of the object struck increased. This, howerer, is not necessarily so. An clongated shot may be so constructed that its axis shall remain a tangent to the curre throughout the whole flight, so that such projectile will almays fall point foremost on the object struck.

This has been proved by experiment, in a mamer which placed the truth of it beyond a doubt. In fact, I myself made the experinent with a 7 -inch rifle gun at Shocburyness.

What I lave just stated shows that the thiclness of metal for ressels constructed with sloping sides cannot safely be diminished.

Should the ressel roll (and who can assert that they will not, and that henrily) where will be the use of the sloping sides?

When the guns have to be worked on the topy of the sloping sides, the effect of the ricochet of the broken shot, \&c., from what may well be called an iron glacis, will probably be most destructive.

The third method, namely, that of dispersing the force of the shot before the latter lias time to penetrate the sides of the vessel, appears to me to be the one likely to be attended with the grentest efficiency, convenience, and economy. The "IVarrior," and other iron-cased firigates, are examples of this principle in its most prinitive form. These ressels have wooden sides, and to prerent the penctration of shot they are simply conted with plates of iron.

The proposition to construct the sides of the vessel with iron, placing rood outside as a protection, is the same in principle, and would donbtless bo more efficient in preventing the complete penetration of solid shot; but the facility with which a coating of rood, or indecd of any soft substance, would bo destroyed by shells, puts this method ont of the question. I entertained the above idea some time ago myself, but discarded it for the reason $I$ haro mentioned.

With respect to the wooden vessel coated with solid iron plates, there appear to bo several almost insurmountable objections to their permanent adoption. In the first place, it rould appear to be necessary, after a ship of this description has been laying up for some time, that she should be stripped of her armour from stem to stern before she can be honestly pro- 
nounced fit for service again. Furthermore, in order to ensure the requisite protection, the iron would have to be nearly, if not quite, as thick as if she had no wooden sides at all.

The method which I have now to submit to the consideration of this meeting is one which I believe will be found better calculated to attain the desired ends than any of those which I hare mentioned. It is, I believe, quite a new idea, and consists of protecting an iron ressel with iron numour. This armour, to which we have given the name "louvre-plate," on account of its similarity to a louvre-board, or, what will be more easily understood by most, a "jalousie blind," is the joint invention of Colonel de Bathe and myself, and is the result of much careful consideration, coupled with some hnowledge of and experience in the effect of heavy rifle projectiles.

The diagrams will show more fully the arrangement and disposition of the metal, and may be thus briefly described. Upon the sides, say $2 \frac{1}{2}$ or 3 inches in thickness, of an iron ressel, are placed the plates one above the other in the manner shomn, learing an interstice betreen each which might adrantageously be filled with an elastic substance, such as New Zealand flax, junk, \&c. In this instance the plates are supposed to be $2 \frac{1}{2}$ to 3 inches thick, and the interstices 11 inch; but this, as well as the thickness of the plates, is arbitrary, and will depend entirely upon the size of the ressel and upon the relative protection which it may be considered desirable to afford her.

By this means we get rid of a rery large portion of weight; in fact, reckoning that of both the iron and wood, in such ships as the "Warrior," the reight would be orer one-fourth less.

It will be perceired by this peculiar disposition of the metal, that the force of a shot's impact is felt, not in the direction of its flight, as in the case of a solid plate, but at the point above it, and therefore the effect upon the hinder plate is enormonsly reduced. Very little solid resistance is offered to the first impact of the shot; but the quality of elasticity, so largely possessed by iron, is made subservient to resisting the effect of impact in a rery great measure.

I mould further draw your attention to several other adrantages which this arrangement possesses in a high degree, one of the most important of which is the ease with which any damage may be repaired by means of spare plates; so much so, that a ressel may carry them and repair her damages at sea.

Again, the effect caused by a slot striking the side is confined to a smaller space than is the case when a large solid plate is struck (more especially when the plates are not penetrated), since the whole plate, which may have a surface of 70 or 80 square feet, is affected by the blor. An elongated shot, from the unequal resistance which it would encounter upon its fore-end, would hare its penetrating porrer rery much more lessened in striking plates of this lind, than in striking those presenting a surface offering a uniform resistance, from the greater ease with which the equilibrium of their axes would be destroyed. It will howerer, I beliere, be found impossible to entirely prevent the sides of a ressel being penetrated by solid shot. There is a limit to the thickness and weight of iron which a ship can carry; but the limit to the weight of the projectile, and the 
force with which it can be driren, has not ret been reached. All me can at present hope to do is to prevent the penctration of the rery destructive elongated shells which are now coming into use. The best course to be pursued, as it appears to me, would be first to ascertain what extra reight ships of each class could carry on their sides without much impairing their sen-going qualities, and then to distribute that reight of metal in the most efficient manner for her protection.

The experiments made upon the "Trusty," as described by Captain Halsted, although extremely raluable, I look upon as being far from a conclusire proof that that description of plate would afford so great a protection to ships as alleged. In this instance, single guns only were fired each time nt her. Norr, in order to form a correct estimate of the efficiency of these plates, or, indeed of any methocl of protecting ships of war, the ressel experimented upon should be moored, or placed in a position where a large frigate could steam past her, delisering her broadside as in action. It is highly probable that the effect produced by two or three shots striking the same plate simultaneously, rould prove more destructire to it than if it were struck by them at scparnte interrals. Tro or three broadsides of heavy guns mell delivered, at a distance of 50 or $100 \mathrm{gards}$, might possibly from the sheer force of the concussion so damage or loosen her plates that a few well-directed shots might suffice to place her at the mercy of her antagonist.

It has been stated that a solid 4-inch plate offers a greater resistance than four 1-inch plates placed apart-that the resistance, in fact, is as the square of the thickness; that is, in the case of the 4-inch plate, this resistance is as of sixteen, whilst with the four 1 -inch plates it is only as of four. This is perfectly true as regards the punching machine, or any similar contintously cxerted force; but quite erroneons with respect to a shot's impact. A punching machine of sufficient power to punch a hole in an inch plate will not only punch holes with equal facility through four, but through four hundred, if necessary; but a shot may penetrate an inch plate, and not be able to penetrate tro placed one behind the other. One is a question of continued pressure on the inch, the other of impact and relocity. Solidity only would resist a large continuous pressure; but the effect of a shot's impact will be impaired by any diminution in its relocity; and the relocity may be diminished in varions rays-in fact, it begins to be diminished the moment the shot leares the muzzle of the gun.

I grant that, if these lourre-plates rere placed under a punching machine of sufficient porrer, they wonld be penetrated much more easily than a solid plate of the same thickness, because, in the punching machine, time is of no account; but the time which would be required to bend these plates down is of immense importance in destroying the effect of a shot's impact, since it would cause the force of the shot to be rapidly dispersed in each direction.

Although, in the experiments which have been made against iron plates, the form of the projectile, and the metal of which it should be composed, are questions of great importance, I hold that they have engrossed an undue share of attention, and that scarcely sufficient regard has been paid to the force of propulsion. At short distances, the form of the projectile is of small importance compared with the degree of force which is emploged 
in its projection; thus; with $a$ gum of a given weight, I believe it will be found to be of more importance in close nction to employ a heary charge of powder and a lighter projectile, than a hearier projectile and light charge of powder; for it must be remembered that it is the propelling force, i.e. the charge of powder, which drives the shot through. Now, although the charge for rifled canmon is a comparatively limited one, because, when exceeding a certain proportion, the shooting becomes wild, yet, at short distances, where great accuracy is not of so much consequence, a very heary charge may be used with great effect. It has been proposed to increase the weight of projectiles employed against iron plates, diminishing the charge of powder. Now, were it an easy matter to penetrate both sides of an iron ship, this proposition monld be reasonable; but, in the present state of affairs, it is altogether an erroneous iden. In support of what I hare stated with regard to the effect of a shot's impact, I will quote a passage from Sir Howard Douglas's valuable work, "Naval Gmmery," jage 77 :-

If an oblong shot, twice the weight of 2 round shot of equal diameter, be fired with the kame charge, the velocity of the former will be less than that of the latter, in proportion as the square root of the weiglit is greatcr; that is, the weight being as 2 to 1 , the relocities will be as 1 to $\checkmark 2$. But the effect of impact, measured by the rolume of penetration, being as the weight of the shot and the square of its relocity, it follows that with equal charges the effect of the ollong shot will le just equal to that of a round shot of equal diameter.

From the above, therefore, it is evident that the charge of porrler being constant, no additional weight in the projectile will increase the effect of its impact. The reason why the 68-pounder 95 -cwt. gun has not jet been superseded in our naval service, lies in the simple fact, that a charge of $16 \mathrm{lb}$. of porrder can be fired from it, and neither Sir William $\Lambda$ monstrong nor M[r. Whitworth lare been able litherto to produce a gan capable of surpassing it on this point. With a view of beating the heaviest smoothbores in the serrice upon every point, I have had a rifle gun constructed upon a principle of $\mathrm{my}$ own, from which a charge of $21 \mathrm{lb}$. of powder can be fired with perfect ease and safety, and with projectiles of any weight, from $120 \mathrm{lb}$. to $180 \mathrm{lb}$, or more, as may be deemed most alvisable. It may, perlaps, have come to your knowledge that this gun has already been triel with very remarkable results, and a further trial is about to take place.

On the first oceasion the cliarge was increased from $21 \mathrm{lb}$. to $28 \mathrm{lb}$. of porder, the projectiles being $175 \mathrm{lb}$, in weight. Nine rounds were fired, chiefly with a view to test the strength of the gum, and upon this, as indeed upon every other point, the result was most satisfactory. In order to try the gun (which I may lere observe loads at the muzzle) to the utmost, three rounds ont of the nine were fired at an eleration of $37_{2}^{10}$; two with $25 \mathrm{lb}$. and one with $28 \mathrm{lb}$. of powder. The range attained was rery nearly six miles, and the penctration into the earth totally prevented the recovery of the slot, and could not be ascertained; the time of flight of these shot was from $37^{\prime \prime}$ to $40^{\prime \prime}$. No iron plato which las yet heen placed on on $\Omega$ ship's side could $I$ think resist the impact of a shot from this gum at any distance within 2,000 yards or more; and if Sir Howard Douglas's method of calculating the effect of the impact of shot be (as it doulthess is) correct, these shot ronld have the same fore at any point 

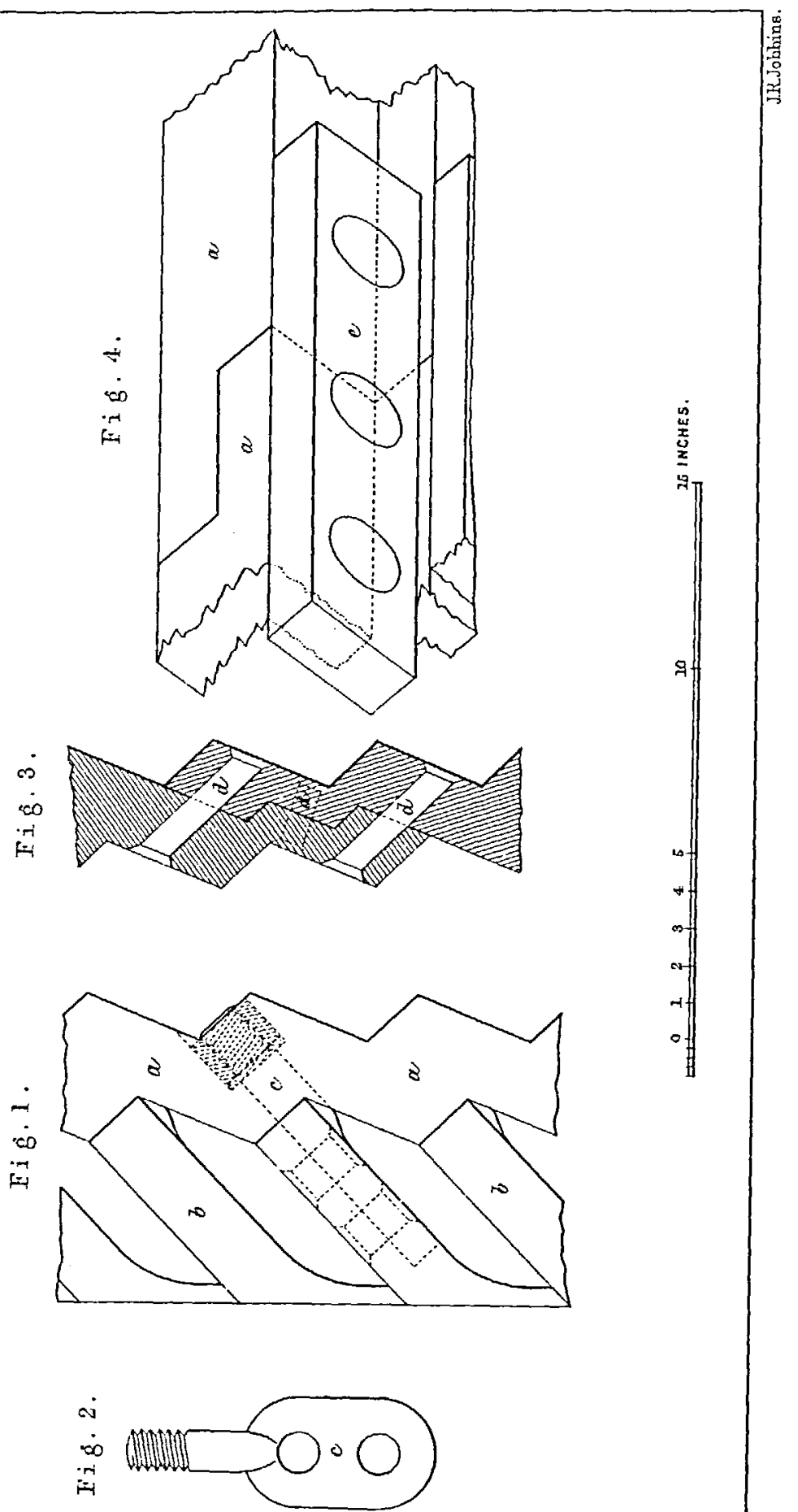
within that distance, as that of a 68-pound shot when it first leaves tho muzzle of the gun, since tho mean velocity of flight in passing over a distance of 2,150 yards was exactly 1,200 feet a second, the time of flight being $5: 31$ seconds. I believe it is in contemplation to arm the "Warrior" and ships of her class with thirty-six 100-pounder Armstrong guns, which are of about 4 tons cach, whilst the gun $I$ have just mentioned is of about 6 . tons. Now it appears to me that twenty-four gons of this description would prore a much more efficient armament than thirty-six of the Armstrongs, which have not shown much power against iron plates. There wonld be besides sereral adrantages attending such a change. One of which would be, that two portholes only would be necessary where there are now three, and that in the future construction of this class of ressel the parallel sides rould require to be of less length by 90 feet, since the same intervals only (15 feet) would be required for the purpose of working the guns. Those who heard Mr. Scott Russell's most interesting lecture at the Institution of Naral Architects will both understand and appreciate this suggestion.

But to return to the subject more immediately under discussion, I would remark that I believe no sea-going ressel can carry plates of any description which shall render her sides proof against the penetration of solid shot, and therefore that these ressels should only be protected as far as may be possible, without depriving them of other and vitally important qualities, and this, I beliere, may be done in a manner to prerent the penetration of incendiary and explosive projectiles of $a$ rery heary description, by some such distribution and arrangement of the metal ns that which $I$ hare nor the honour to introduce to your notice.

A powerful armament and great speed are matters of the very highest importance, and not to be lightly sacrificed; in fact, an iron-cased ressel wanting these qualities would present a mere inert target to a more active and better-armed opponent; and her certain capture and destruction rould be simply a question of time. $\Lambda$ ship of war is commissioned to "bum, sink, and destroy," and not simply to save herself from being burnt, sunk, or destroyed. In conclusion, I would remark that, having no experience in ship-building, but haring had great experience in the effect of shot upon various materials, I hare regarded the sides of a slip in this question in the light simply of a protection ngainst destructive missiles, that is, in what manner the greatest protection can be afforded with the employment of the smallest possible weight.

The following is an explanation of the plate:

Fig. 1 represents a transverse section of the side of an iron ship protected by the armour-plates, $a$ a being the side or skin of the ship of a zigzag form; $b b$ the outer or "lourre" plates; $c$ is the bolt which fastens the latter on to the former. The spaces between the lourre plates may be filled rith some elastic substance.

Fig. 2 gires a front view of the bolt $c$.

Fig 3 shows the mamer in which the inside plates are connected one with another in a longitudinal direction, $d r d$ being the rivets, which are placed at certain interrals apart.

Fig. $A$ is a front riew of the rertical join, a a being the plates which 
form the side of the ressel, and $e$ the plate which is placed at the back to strengthen them at the joint. This plate is also inade fast with three rows of rivets.

In reply to rarious questions, Mr. Thomas sinted that the gross reight inrolred in the proposed form wonld be one-fourth less than, and, according to the calculations of a rell-known Iron Company, the expense about one-half (25l. instead of 50l. a-ton) the expense of the "Warrior,"-that the saving would result chiefly from all the plates being rolled at the cost of about 81 . a-ton, Thereas the "Warrior's" plates are very expensive, especially where there is tongueing and grooving,-that repairs could be made with great facility, without disturbing any but the injured parts. The width and thickness of the armour-plates ronld be adapted to the size and tonnage of the ressel. It will be impossible to gire a small ressel a protection equal to that of a large ressel; the effect of the shot's inpact is diverted, so that the blow upon the inner plate is not felt in the direction in which the shot is moring, but at a point abore it, which considerably lessens the destructive effect. The spaces betreen the plates may be packed or not with some elactic substance, but the packing was objected to as giring rise to the deposit of a grent deal of moisture. The inside plates of iron, or skin of the slip may be flat iustead of a zigzag form, but the latter offers a better resistance to shot.

The Chainunix conroyed the thanks of the meeting to Mr. Thomas for his interesting and instructire paper, and the proceedings then terminated. 